\title{
PERSPECTIVES AND OPPORTUNITIES OF GEORGIAN FINANCIAL MARKET INTEGRATION INTO EU
}

\author{
Asie Tsintsadze ${ }^{1}$, Doctor of Economics, Professor; Irina Vashakmadze ${ }^{2}$, Doctor of Economics, \\ Associate Professor; Irina Tavadze ${ }^{3}$, Doctor of Economics, Assistant Professor; Lilit Meloyan- \\ Phutkaradze ${ }^{4}$, Doctor of Economics, Assistant Professor \\ 1,2,3,4Batumi Shota Rustaveli State University
}

\begin{abstract}
Full integration of the financial market with Europe is a necessary requirement of a market economy. The circulation of financial resources between different countries of the world creates opportunities for the growth of the economy of each of them, as the share of foreign investments both inside the country and abroad increases. The ability of developing countries to integrate with Europe is limited because of their economic situation. The aim of this paper is to identify the obstacles and opportunities that hinder or facilitate the integration process. One of the reasons for the inadequate extent of liberalization of financial flow is the inadequate development of the financial market. The main financial institutions that are promoting the flow of funds in the financial market under the guidance of the European Association Agreement directives are primarily development oriented, although the socio-economic situation impedes the implementation of certain directives or the proper success is not achieved. The inflow of foreign investment into the Georgian economy is not problematic, although only oneway movement of financial resources cannot ensure full integration. Especially the initial phase of European directives involves the movement of finances through the opening of branches in European countries. In the article, the economic growth achieved before and after the European Association Agreement in the development of the financial markets will be an indicator of the opportunities and prospects for European integration. The empirical analysis method is used for the evaluation, the role of banking and insurance institutions in the development of the stock market has been studied, problems have been identified and recommendations have been formulated to improve the financial market.
\end{abstract}

Key words: European directive, Banking institution, Insurance institution, Stock market.

JEL code: G1,G21, G22, G23

\section{Introduction}

The integration of the financial market with Europe implies the liberalization of financial flow. This is a vital source for boosting the economy of a developing country, as it promotes foreign investment within the country and beyond. The development of the financial market at the level of one country requires passing through several stages: 1) Creation of financial institutions based on the need to move the country's financial resources; 2) Attracting foreign investment to expand financial globalization; 3) Development of financial instruments created; 4) Liberalization of financial operations (Tsintsadze., Phutkaradze, 2017). The development of global financial markets using financial instruments that were created in the 1990s, when the post-Soviet countries did not even have the rudiment of an independent financial market, has ended. Consequently, European integration proceeded at a slow pace. The main purpose of the article is to identify the opportunities for European integration, based on the assessment of the development of the financial market. To this end, the consequences of the Agreement on the European Association and statistics on the economic development of financial institutions will be studied, on the basis of which we can discuss the possibilities and prospects of European integration. Using empirical analysis, the article identifies trends in the country's financial market development, comparing it with the level of development of financial institutions in European countries and outlines opportunities and problems associated with the implementation of the association directives in relation to both market development and European directives. The information sources used includes the data of the Organization for Economic Co-operation and Development, and the National Statistics Office Georgia, and the National Bank of Georgia. 
The issues of integration of financial markets have been analysed in papers published in 1973 (McKinnon, 1973 and Shaw, 1973). Both scholars disapproved of the policy of restricting financial markets, believing that this policy would result in a shortage of financial resources as well as a nonoptimal distribution of financial resources across sectors. Both authors acknowledged that this approach caused low economic growth in developing countries in the 1950s and 1960s and that liberalization of financial markets would lead to increased investment, which in turn would contribute to economic growth. Researchers from Asian countries take different approach to European integration. "It is argued that the European way cannot be directly emulated into the Asian case. Heterogeneous economic conditions, historical, and political regimes mean that the approaches must differ between the two regions. Small Asian economies are confronted with susceptible capital flows, which implied economic stability" (Kumari Selvarajan,Ab-Rahim, 2020). We agree with the authors that perfect financial integration cannot be achieved under different political interests, but it is an inevitable process, as confirmed in the same paper. "Financial Integration and Economic Growth: Should Asia Emulate Europe? is inevitable, and now it is only a question of time and pace."

Theoretical and practical studies prove that the banking and insurance sectors and the stock market play a vital role in ensuring the key function of the financial market - the reproduction of financial resources, providing the market with temporary free resources, thereby creating an opportunity for investment. (Tsintsadze, Vashakmadze, Tavadze, Meloyan-Phutkaradze, 2019).

Research findings and discussion

Over the past two years, the National Bank of Georgia has developed, improved, and implemented numerous regulations, which in the short term will slow down retail lending, increase expenditures in the sector, increase capital demand and reduce profitability in the short term. In the long run, we should hope that this will contribute to a qualitative improvement in the financial system of Georgia, which will ultimately ensure the financial stability of the banking system. In particular, the change in lending rules for individuals set rigid boundaries to financial sector, which led to significant changes in lending procedures. Lending without an in-depth analysis of solvency has stopped. There is no uniform methodology for estimating the excessive lending. Important criteria that can give us an idea of its scale is the share of inactive loans in the banking sector. According to these criteria, Georgia has one of the lowest rates in Europe and in the region, per IMF's information it is $2.7 \%$ of total bank lending. For comparison, many European countries have several times larger overdue loans (Denmark - 4.2\%, Ireland - $9 \%$, Italy - $9.8 \%$, Russia - $10 \%$, Portugal - $11 \%$ ). The International Monetary Fund (IMF) downgraded its forecast for economic growth in Georgia. According to a statement released by the Fund's mission in Georgia in 2019, it amounted to $5.2 \%$, which exceeds the IMF's forecast of $4.6 \%$. That is below the forecast of $4.78 \%$ of October 2018 by $0.18 \%$ percentage point. The growth outlook for 2020 is stable and the growth forecast is $4.3 \%$. According to the IMF, one of the main risks of economic growth is changes in the rules for lending to individuals.

From January 2019, new banking regulations came into force and banks were restricted from lending to citizens without a detailed analysis of their income. In addition, the income groups were defined and the maximum loan ratio was set for each group. A year after this change, the Georgian government is working to amend them. As it is known, bank regulations are expected to soften by March, which means that thousands of citizens will have access to loans. 


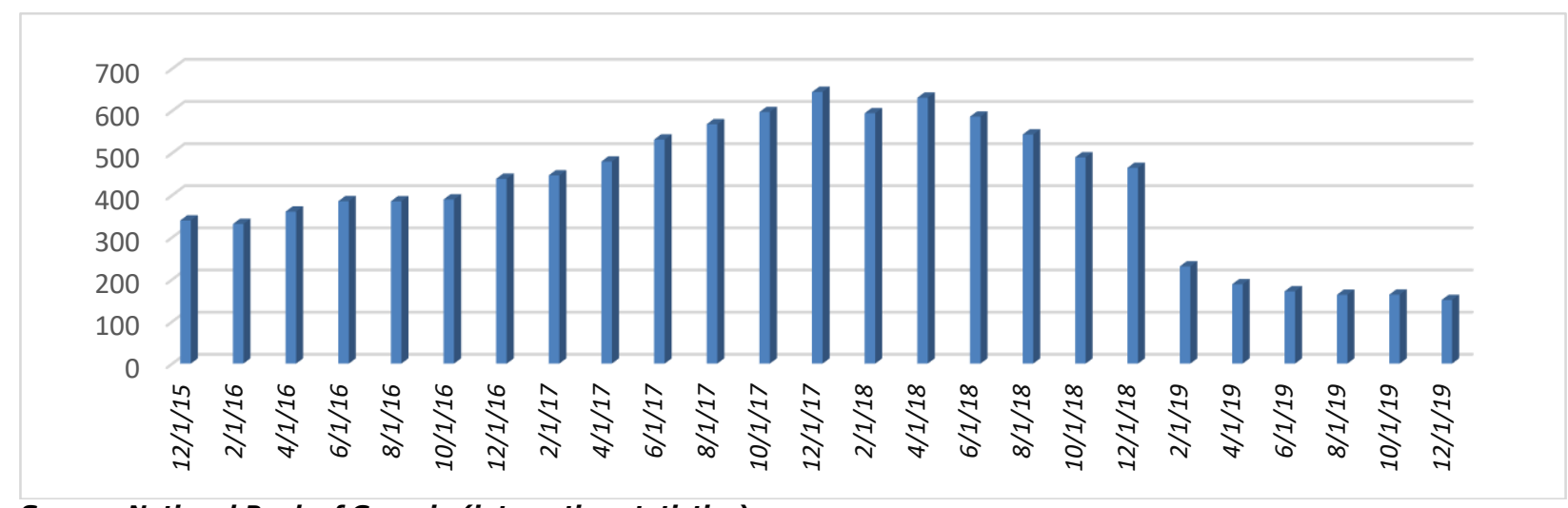

Source: National Bank of Georgia (interactive statistics)

Fig. 1. Consumer Loan (thousand GEL)

As the diagram shows, among individual loans, the short-term consumer loans are most reduced. In December 2019, the volume of consumer loans issued in monetary form, decreased by $74.23 \%$, from 586,055 GEL thousand to 151,005 GEL.

A reduction in lending automatically means a decrease in the amount of disposable free funds, which leads to a decrease in total local demand. Demand reduction in turn has a negative impact on business sector revenues and the expenses incurred / to be incurred by them. As a result, economic activity and growth rates decline in the short term.

According to a statement by the International Rating Company Fitch, dated February 22, 2019, it was this regulation that became one of the factors that contributed to the improvement in credit ratings.

Even when looking at the same profitability statistics, in 2019 no negative effects are observed. In particular, banks maintained a fairly high level of profitability. Net annual income increased by $34 \%$, and interest income increased by $12 \%$. Thus, banks were not affected by the regulations.

Over the past six years, individual loans have increased from $15 \%$ to $40 \%$ in respect of GDP. At the same time, lending growth rates were also quite high compared to the economic growth rates. In particular, over the past 3-5 years, annual credit growth has been above $20 \%$. If debt grows faster than its servicing ability, within a few years it will inevitably cause severe problems for borrowers, the financial sector and the economy as a whole.

Compared to other countries, Georgia has a softer approach to income verification. In particular, banks have the right to take into account incomes from the informal sector, as was the case before the regulation, which is quite rare in international practice. According to world practice, the insurance sector plays an important role both in providing credit resources and in developing the stock market. It is therefore important to study the dynamics of development for each.

The development of the single insurance market in the EU was carried out gradually under the directives developed in 1973, 1988 and 2002. The directives adopted in Georgia in 1973, 1988 and 2002 could not be implemented because of the simple reason that the country was a member of the USSR. The affirmation of European values in the Georgian insurance market dates back to the creation of the European Economic Community on 18 December 1989, which was expressed in support of the independence of Georgia. This became the basis for the creation of the first private insurance company "Aldagi" from the very beginning of independence, the initial capital of which was created through contributions from Georgian and foreign partners. It has already become a precedent for the insurance market to develop in the footsteps of the European insurance market. The harsh 
socio-economic conditions on the path to development made it difficult to implement the directives set for the insurance market. The first step was the creation of a supervision service, which served as the basis for the development of regulatory laws and legal acts. In parallel mode, the launch of market development measures and economic development programs in the country allowed the gradual implementation of European integration directives of 1973, 1988 and 2002. The purpose of this article is to assess the quality of integration in relation to the development of the insurance market, the main indicator of which is the amount of premium attracted.

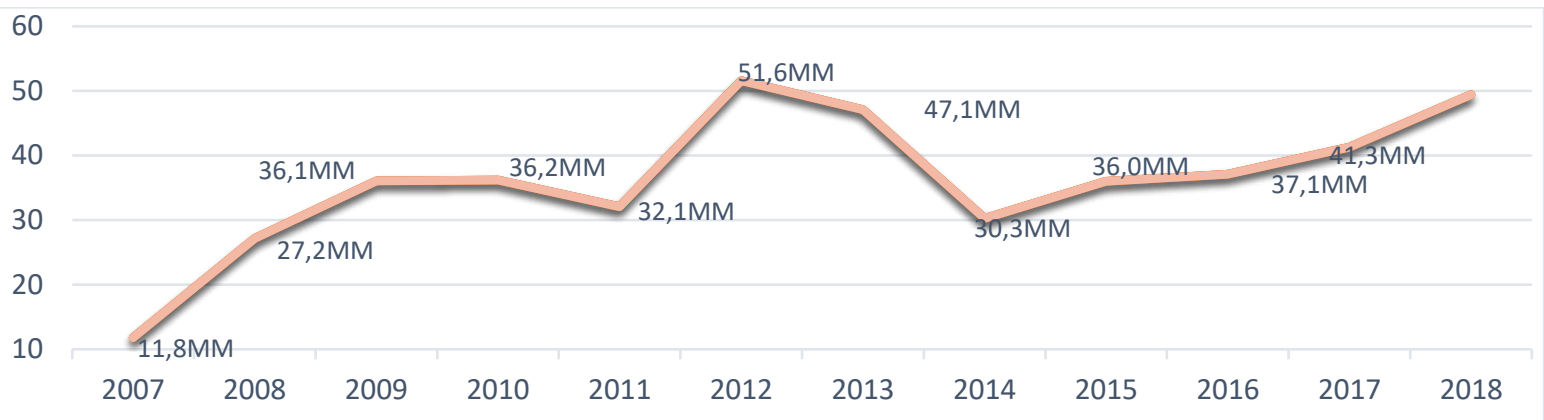

Source: LEPL Insurance State Supervision Service of Georgia, https://www.insurance.gov.ge

Fig. 2. Premiums Attracted in the Insurance Market 2017-2018

The diagram shows that the volume of attracted premiums is not steadily increasing. The reason for this is excessive politicization. Specifically, in 2012, the new government's policy reduced the monopoly on the market and allowed companies to operate in free competition (which is one of the requirements for European integration). The reduction in premiums attracted since 2013 is driven by the introduction of the Universal Healthcare Program. This regulation, on the one hand, brought the country closer to European values in relation to the protection of human rights, and on the other hand, stimulated the development of insurance companies by introducing new insurance products (LEPL Insurance State Supervision Service of Georgia, 2018). Health insurance was one of the most vital products for existence of the companies. In terms of product diversity, the Georgian insurance market is still far from the European market due to low incomes, low risk awareness and low insurance culture. Accordingly, the share of the insurance sector in GDP is very low $(1.18 \%)$ compared to European countries, as evidenced by the value of the penetration rate of insurance on this chart.

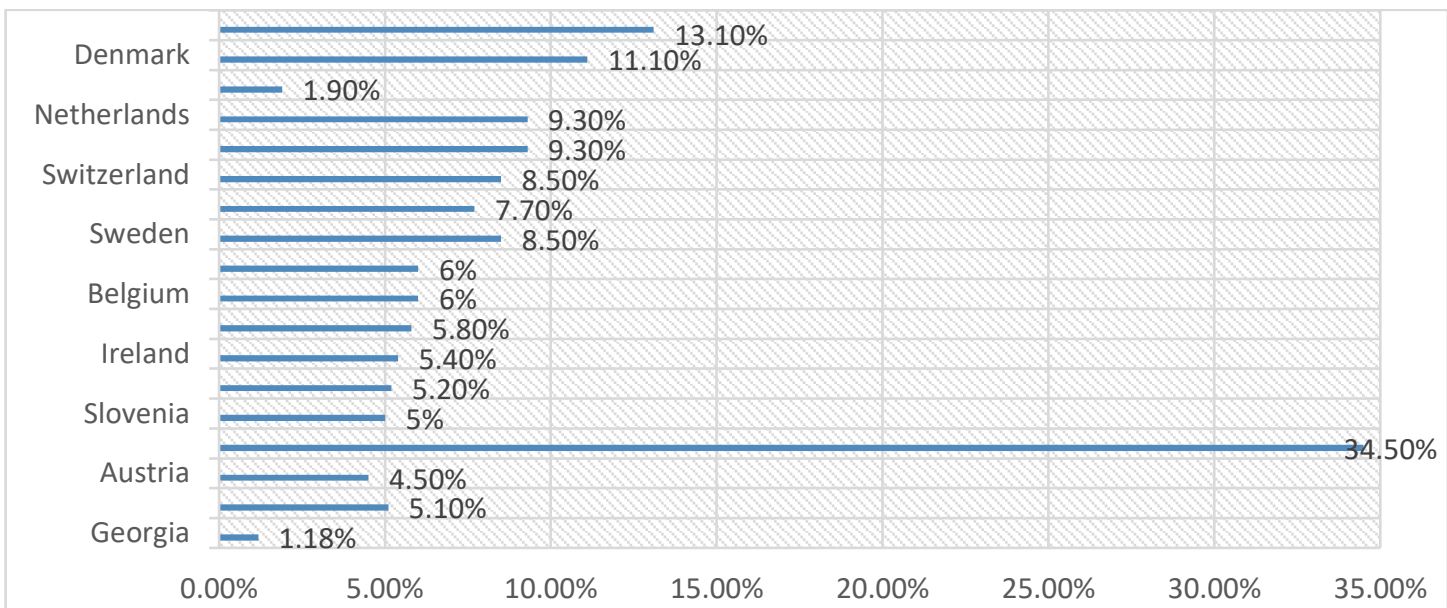

SOurCe: ORGANISATION FOR ECONOMIC CO-OPERATION AND DEVELOPMENT; LEPL Insurance State Supervision Service of Georgia 2018

Fig. 3. Insurance penetration: Europe and Georgia, 2018 
Is there a problem with complying with insurance supervision rules? Given that the rules of supervision are fully consistent with the rules of European countries, there are no problems in this regard, but the main thing is not only compliance with the rules, but also regulation of factors conducive to development, such as population income growth, the introduction of compulsory insurance in some areas, tightening control over compensation for losses, as unreasonably uncompensated losses, prolonging the duration of disputes further undermines trust in insurance companies. The second indicator that can be used to estimate population involvement in the development of insurance is the density of insurance.

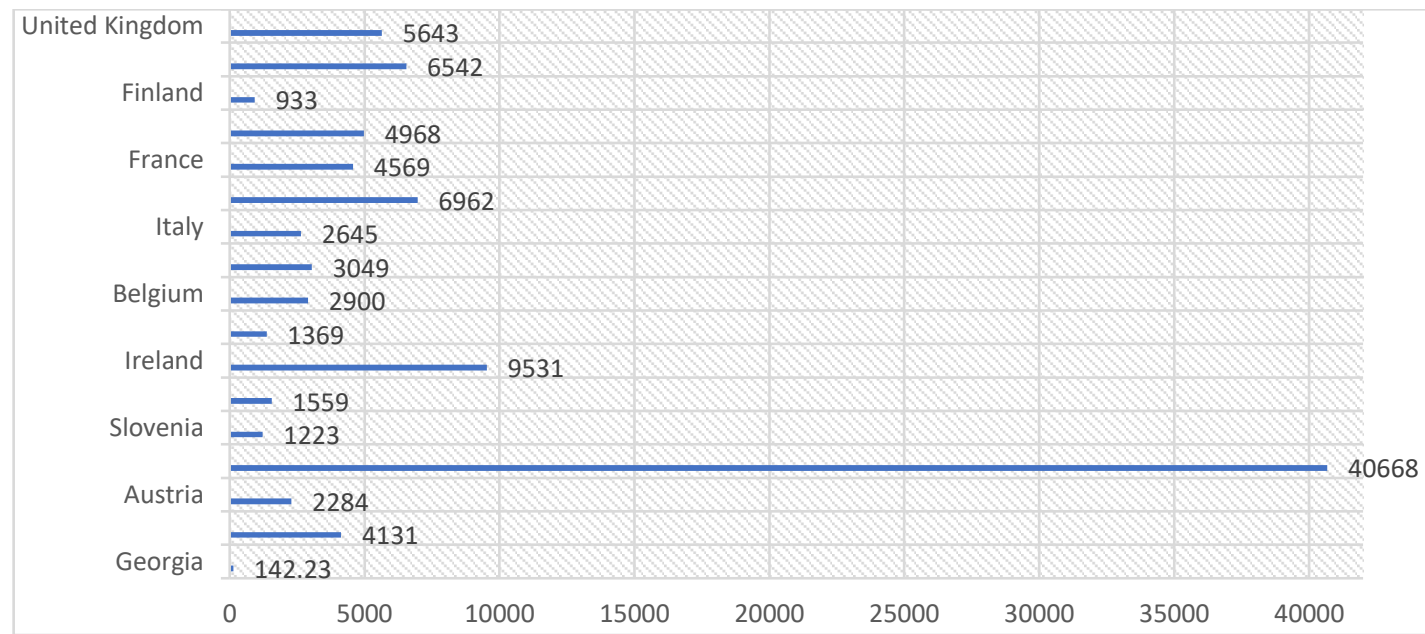

SOURCe: ORGANISATION FOR ECONOMIC CO-OPERATION AND DEVELOPMENT; LEPL Insurance State SUpervision Service Of Georgia, 2018

Fig. 4. Density of insurance: Europe and Georgia, 2018

In this case Georgia has the lowest rate of per capita insurance premium. Apart from the problems mentioned above, life insurance is underdeveloped. The increase in risky life insurance from $1.57 \%$ to $6.9 \%$ for the study period is due to the requirement of the banking sector, which obliged the borrower to insure his/her life to minimize risks. Providing funds to the financial market can be achieved not at the expense of risky life insurance, but at the expense of accumulated life insurance. Therefore, it is obvious that in Georgia, where the accumulated life insurance is in its infancy, the role of the insurance market in the development of the financial market is accordingly small (LEPL Insurance State Supervision Service of Georgia, 2007-2018). The circle of problems that hinder the full integration of the insurance market with the European insurance market is as follows: 1) Low insurance culture of the population; 2) Neglect of the expected risks by both the legal entities and individuals; 3) Underdeveloped accumulated life insurance; 4) The problem of placing free reserves of insurance companies in high-yield securities due to the underdeveloped stock market, consequently leading to low investment return of the companies. The amount of premium attracted is directly related to the number of contracts. The authors argue that, along with all other problems the development of the insurance business is hampered by the weak regulation of loss reimbursement process for emerging insurance cases. "The insurance contracts in highly regulated countries cost 74 per cent more than the contracts in the least regulated countries: consumer protection seems to be very costly." (Finsinger, 1992).

The above problems prevent insurance companies from directly participating in the financial market, limiting themselves to the placement of free reserves in bank deposits. According to the latest data, financial resources placed on bank deposits make up $60-70 \%$ of insurance reserves, resulting in an investment return of $3.8 \%$ of total income. One of the important directives of the 
Association Agreement with Europe is the introduction of the solvency margin methodology. The Solvency I requirement (on the publicity of liability and reporting, risk management and capital adequacy) has been fulfilled in Georgia since 2011. As for the Solvency II Directive, it can be implemented from 2020, which is preceded by a gradual increase in regulatory capital in both the insurance and reinsurance sectors. The situation of the financial institutions reviewed confirms that the share of securities market in the country is not much developed (Tsintsadze, MeloyanPhutkaradze, 2018).

In Georgia, the stock market, where large volume of securities should be traded permanently, is virtually frozen. Although, with the support of the US government, the best American experts in this field from USAID in 1998-2000 laid the foundation for the securities market. In their Law on the Securities Market, the securities industry was separated from its natural competitor - the banking sector, to give the newly established securities market mechanism a real opportunity to develop independently. Under this legislation, in 1998-2000, the basic infrastructure of the securities market (the Georgia Stock Exchange, the Central Securities Depository of Georgia, up to 12 independent registrars) was created and launched, up to 40 brokerage companies were created and commissioned etc. The securities market in Georgia was gradually gaining ground in 2000-2007. However, amendments to the law on the Securities Market, which took place in 2007-2008, discredited the securities market.

- It became possible to trade without an exchange market, with more than $95 \%$ of the transactions being traded outside the exchange market in a nontransparent and non-competitive environment. This has led to a loss of investor confidence in both the securities market and the entire market. This will ultimately lead to a significant drop in market liquidity.

- The independent regulator was called off, and control over the securities was transferred to the National Bank. The priority of the National Bank is always commercial banks and it is less interested in the development of free exchange trading.

- Commercial banks were allowed to buy a controlling stake in the stock market. Finally, banks own more than $50 \%$ of the stock exchange and, according to the charter, have the majority of votes among decision-makers. This allows them to run processes independently, at their discretion.

- It should also be noted, based on the foregoing, what role does the insurance market play in the development of the stock market, if any. As the analysis shows, the share of accumulated life insurance is almost zero, therefore companies do not have long-term financial resources that could participate in investing in securities traded on the stock market. Accordingly, it acts as a mechanism for distribution of shares between companies and not a mechanism for investing.

Notwithstanding the foregoing, it should be noted that the steps taken by the National Bank of Georgia and the Government in developing the securities market, which the Association Agreement requires from the state, are not insignificant.

1) In 2017, part of the amendments to the Tax Code entered into force, which introduced tax exemptions for the taxation of loan and equity financial instruments. Under the first amendment package, capital gain is not taxed, which encourages secondary market activity. In addition, coupons for corporate bonds issued before 2023 will not be taxed, and dividends paid on shares will be deducted from the source of payment.

2) Since 3 December 2018, the National Bank of Georgia and Company "Montran" have implemented an integrated securities settlement system GSSS, which is used to issue, store, repay and pledge government and private securities. Despite the fact that a little over a year has passed since the 
introduction of the system, it has already attracted the attention of participants from central banks and capital markets from around the world and has been highly appreciated by various experts on the international infrastructure market. And on 7 February 2020, the CENTRAL BANKING Award was presented to the National Bank of Georgia and the "Montran" Company for this innovation. The award ceremony will be held on March 19 th in Brussels, Belgium, by CENTRAL BANKING.

3) Draft Law on the Development of Derivatives Market, developed by the National Bank in cooperation with the European Bank for Reconstruction and Development (EBRD) was adopted by the Parliament of Georgia on 20 December 2019. It will regulate the operations of created instruments, determine the netting ability of derivative parties and the use of financial mortgage. In addition, the National Bank of Georgia is actively promoting the development of the debt securities market. Namely, by a decision of the National Bank of Georgia, in 2014, commercial banks were allowed to use GEL-denominated corporate debt obligations to provide refinancing loans. As a result, demand of commercial banks for these product has increased significantly. In 2014, as part of the de-dollarization strategy, the National Bank of Georgia allowed international financial institutions to issue GEL-denominated debt obligations. Since December 2016, the National Bank of Georgia has launched a new one-month open market monetary policy instrument.

As a result of these approaches, the volume of debt securities in the market has increased significantly, and growth continues. Along with monetary market instruments, the government debt securities market also plays an important part in the development of the corporate bond market. Over the past few years, the volume of government debt securities in the market has increased.

According to the NBG, foreign debt securities issued by companies operating in Georgia by November 2019 exceeded 7 billion GEL, most of which comes from financial sector and state-owned companies ( $80 \%$ ). In addition, more than $91 \%$ of the bonds are denominated in foreign currency.

Georgia holds a leading position among the following European countries in terms of the share of issued debt securities in GDP: the Czech Republic, Slovakia, Turkey, Estonia, Hungary, Russia, Slovenia, Poland, Bulgaria, Croatia, Latvia, Lithuania, Romania, Ukraine. The debt securities market has grown almost 2.8 times since 2014. The largest share of the emission falls on bonds issued abroad by corporations and treasury bonds ( $52 \%$ and $35 \%$ of the market, respectively).

The treasury securities market facilitates the mobilization of local and international investors. The development of this market segment, is an important prerequisite for the development of corporate bonds, which is also proved by international experience. And this, in case of sufficient development of the capital market, liquidity and existence of investor market, indicates a potential for market growth. Indeed, the above problems hinder the development of the securities market and, accordingly, its share in the country's GDP is $6 \%$ and is listed on the next-to-last position among the given European countries.

Thus, the state plays a major role in the development of the securities market in developing economies. The securities market is an indispensable and important element of the global economy without which a sustainable development of the economy is not possible.

\section{Conclusions and recommendations}

As a result of the study, problems of integration of the main players of the financial market with Europe were identified and recommendations were developed. Namely: A reduction in lending automatically means a decrease in the amount of disposable free funds, which leads to a decrease 
in total local demand. Demand reduction in turn has a negative impact on business sector revenues and the expenses incurred / to be incurred by them. As a result, economic activity and growth rates decline in the short term. Based on the above, we consider, that the recommendations made by the European Association Agreement in the short term will lead to a slowdown in retail lending, but in the long run it will contribute to the qualitative improvement of the Georgian financial system, which will ensure the financial sustainability of the banking system.

The circle of problems that hinder the full integration of the insurance market with the European insurance market is as follows: 1) Low insurance culture of the population; 2) Neglect of the expected risks by both the legal entities and individuals; 3) Underdeveloped accumulated life insurance; 4) The problem of placing free reserves of insurance companies in high-yield securities. To achieve full integration, we will consider: 1) Introduction of the mandatory form for certain types of insurance (business property, professional liability, accumulated life and healthcare, all types of vehicles); 2) Development of stock market; 3) We believe that in order to accelerate the integration of developing countries with Europe, the Association Agreement should incorporate not only development directives in a particular area, but also recommendations for creating the basis for development, such as, for Georgia: overcoming unemployment, raising the minimum wage in order to raise living standards to a moderate level. Then it would be possible to free the state from social spending, and the introduction of compulsory insurance would be justified.

The problems that arose as a result of unjustified amendments to the Law on Securities Market led to discreditation of the market that was on the path of development, which affected: 1 ) Quitting the stock market by participating companies; 2) The complete disappearance of some large companies as a result of the 2008 Russian-Georgian war; 3) A small share of the insurance market in the history of securities market development due to underdeveloped life insurance; 4) Assigning a dominant role to the commercial banks in the stock market.

We believe that elimination of the problems identified in the development of the financial market can be achieved through the improvement of the legislative framework, which implies that stock exchange institutions will be fully capable to comply with the directives under the European Association Agreement.

\section{Bibliography}

1. Bank of Georgia - Ratings Navigator. Retrieved: https://www.fitchratings.com Access: 15.01 .20

2. Financial Sector Assessment Program (FSAP). Retrieved: https://www.imf.org/en/Countries/GEO Access: 23.01.20

3. Joaquin Maudosa, Juan Fernandez de Guevara. (2015). The Economic Impact of European Financial Integration: The Importance of the Banking Union. The Spanish Review of Financial Economics. Vol.13. Issue 1. pp. $11-19$

4. Jorg Finsinger, (2019). European Market Integration and the European Insurance Industry: Reasons for Trade, Barriers to Entry, Distribution Channels, Regulation and Price Levels, Tax Harmonization and Financial Liberalization in Europe pp 225-261.

5. LEPL Insurance State Supervision Service of Georgia. Retrieved: https://www.insurance.gov.ge Access:23.01.20

6. Mckinnon, R. I. (1973). Money and Capital in Economic Development. Washington, D. C.: Brookings Institution.

7. Organisation for Economic Co-operation and Development. Retrieved: https://stats.oecd.org/Index.aspx?QueryId=25444 Access: 02.02.20

8. Phutkaradze, B., Tsintsadze, A., Phutkaradze Z. (2019) Financial Integration and Economic Growth: Empirical Evidence from the Republic of Georgia. European Journal of Sustainable Development 8 (2),pp. 232-232.

9. Regulations Implemented according to the Retail Lending. Retrieved: https://www.nbg.gov.ge/index.php?m=726 Access: 05.02.20

10.Selvarajan S.K, Rossazana A, (2020), Financial Integration and Economic Growth: Should Asia Emulate Europe? Vol. 35, No. 1, pp. 191-213. 
11. Shaw, E. (1973), Financial Deepening in Economic Development. New York: Oxford University Press.

12. Stiglitz, Joseph (2004). "Capital-Market Liberalization, Globalization, and the IMF," Oxford Review of Economic Policy, Vol. 20, No. 1, pp. 57-71.

13. Tsintsadze, A., Meloyan-Phutkaradze, L.(2017). Empirical Analysis of Development of Insurance Field. Scientific letters of academic society of Michal Baludansky, 5, pp. 146-149.

14. Tsintsadze, A., Oniani, L., Ghoghoberidze, T. (2018) Determining and Predicting Correlation of Macroeconomic Indicators on Credit Risk caused by Overdue Credit , Banks \& bank systems, Issue13, Iss. 3, pp. 114-119.

15. Tsintsadze, A., Vashakmadze, I., Tavadze, I., Meloyan-Phutkaradze, L.(2019). New Regulations in the Development of a Financial Market. American Journal of Fundamental, Applied \& Experimental Research 12 (1), pp. 96-101.

16. Vashakmadze, I., Glonti, V.(2018). Deposit Insurance, as the Basis for Ensuring Financial Sustainability of the Banking System. Journal of Applied Finance and Banking 8 (5), pp. 43-52.

17. Vashakmadze, I., (2018). Problematic Loan Management in Georgian Commercial Banks. Ukraine-EU. Innovations in education, technology, business and law, p. 334. 